\title{
Men and women do not have the same relation between body composition and bone mineral density in Brazilian people
}

\author{
ALONSO, A. C. ${ }^{1,2 *}$, RIBEIRO, T. C. ${ }^{1,3}$, FERREIRA, R. B. ${ }^{1,3}$, \\ DUARTE, R. ${ }^{2}$, BRECH, G. C. ${ }^{1}$, SILVA, L. X. ${ }^{1}$, BOCALINI, D. S. ${ }^{2,4}$, \\ PETERSON, M. ${ }^{5}$, MAIFRINO, L. B. M. ${ }^{4}$ and GREVE, J. M. D. A. ${ }^{1}$ \\ ${ }^{1}$ Movement Study Laboratory - LEM, Institute of Orthopedics and Traumatology - IOT, \\ Faculty of Medicine - FM, Clinical Hospital - HC, Universidade de São Paulo - USP, \\ Rua Ovídeo Pires de Campos, 333, Cerqueira Cesar, CEP 05403-010, São Paulo, SP, Brazil \\ ${ }^{2}$ Department of Post-graduation in Aging Sciences, Universidade São Judas Tadeu, R. Taquari, 546, \\ Mooca, $2^{\circ}$ andar, bloco C, CEP 03166-000, São Paulo, SP, Brazil \\ ${ }^{3}$ Sports Medicine Group, Institute of Orthopedics and Traumatology, FIFA - Medical Centre of Excellence, \\ Medical School, Universidade de São Paulo - USP, Rua Ovídeo Pires de Campos, 333, Cerqueira Cesar, \\ CEP 05403-010, São Paulo, SP, Brazil \\ ${ }^{4}$ Department of Post-graduation in Physical Education, Universidade São Judas Tadeu, R. Taquari, 546, \\ Mooca, $2^{\circ}$ andar, bloco C, CEP 03166-000, São Paulo, SP, Brazil \\ ${ }^{5}$ Department of Physical Medicine and Rehabilitation, University of Michigan Health System, \\ Ann Arbor, MI, United States \\ *E-mail: angelicacastilho@msn.com
}

\begin{abstract}
Objectives: The main objective this study was to examine if lean mass and the adiposity related with BMD in a eutrophic population of Brazilian adults, in different sites and gender. Methods: A crossectional observational study, without intervention. One hundred non-obese men and women, aged 20-40 years, who did not practice regular physical activity were evaluated. Body composition analysis was conducted by dual energy X-ray absorptiometry (DXA), and multiple regression was used to examine the sex-specific association between adiposity and lean mass profiles. Results: Even after adjusting for age, sex, and BMI, total fat mass was inversely associated with total BMD $\left(\beta=-4.52 \mathrm{~g} / \mathrm{cm}^{2}, \mathrm{p}<0.01\right)$. Lean mass was positively associated with BMD and female groups. In our study the lean mass has a postive effect in BMD for eutrophic Brazilian adults, opposite of adiposity. Although when stratified by gender, in adults women lean mass and adiposity have positive effects on BMD, which did not happen with men.
\end{abstract}

Keywords: bone density, body composition, adults, adiposity, body mass index.

\section{Introduction}

Obesity and osteoporosis are increasing in prevalence, globally, and pose a large burden to public health. Clinical presentation of both is heterogeneous and although widely studied, the interrelationship between excess adiposity and bone mineral density (BMD) is less understood (BOGL, LATVALA, KAPRIO et al., 2011).

Osteoporosis is defined as a loss of bone mass and diminished integrity of the microarchitecture structure, which leads to fragility in the bone and elevated risk of fractures. According to a study published in 2014, the prevalence of osteoporosis in United States was 10.2 million, in people over 50 years (JOHNELL and KANIS, 2006). Risk of fracture coincides with an elevated risk for multiple comorbidities and early mortality.

The convention that higher body mass index (BMI) has a positive association with bone mineral density (BMD) is well supported by the literature (BIAN, LI, YING et al., 2015; VAN LANGENDONCK, CLAESSENS, LEFEVRE et al., 2002; JIANG, ZHANG, JIN et al., 2015). This occurs because of the mechanical overload in the bone is elevated with greater BMIS, leading to activated osteoblasts and inducing bone turnover, the piezoelectric effect and even the traction mechanism of the muscles at the bone.

Studies that have examined the link between body composition and BMD demonstrate that lean mass and fat mass both contribute to loading and the formation of the bone mass. Indeed, many studies show a positive relationship between lean mass and BMD suggesting that a higher BMI predominating muscle mass could be an inductor to the bone mineralization (VAN LANGENDONCK, CLAESSENS, LEFEVRE et al., 2002; JIANG, ZHANG, JIN et al., 2015; PLUIJM, VISSER, SMIT et al., 2001; PARK, SONG, SUNG et al., 2012; SHAO, LI, LIU et al., 2015; HO-PHAM, NGUYEN, LAI et al., 2010).

In relation to the fat mass, there is no consensus. Some studies suggest that fat mass has a negative association with BMD (SHAO, LI, LIU et al., 2015; HO-PHAM, NGUYEN, LAI et al., 2010; SILVA, MENDONÇA, CONCEIÇÃO et al., 2007; ZHANG, PETERSON, SU et al., 2015), while others claim the opposite. As the fat mass is a component of the body composition, there should be the same correlation with the body composition and the BMI (HSU, VENNERS, 
TERWEDOW et al., 2006; KIN, KUSHIDA, YAMAZAKI et al., 1991; ZHU, HUNTER, JAMES et al., 2015).

Various studies have attempted to define which of the components of the body composition is more important to predict BMD (BOGL, LATVALA, KAPRIO et al., 2011; JIANG, ZHANG, JIN et al., 2015). Most demonstrated that lean mass is a better predictor of the BMD. While others have demonstrated that fat mass has a stronger positive correlation with BMD (HO-PHAM, NGUYEN, LAI et al., 2010).

Fat mass could present a negative association with BMD, thus indicating that BMI predominating adipose tissue would be harmful for the bone tissue. In this situation there are many potential mechanisms involved. It is also, where obesity and osteoporosis show interrelationship (BOGL, LATVALA, KAPRIO et al., 2011; JIANG, ZHANG, JIN et al., 2015). Some studies already demonstrated that obesity has several pathophysiological consequences among bones and skeletal muscle. The adipose infiltration into bones could be part of an evolutionary process associated with obesity and cardiometabolic diseases; however, the contribution of low physical activity participation and exaggerated sedentary behaviors is also a primary driver (REID, 2008; GOODPASTER, KELLEY, THAETE et al., 2000; VETTOR, MILAN, FRANZIN et al., 2009; BREDELLA, GILL, GERWECK et al., 2013; GOWER and CASAZZA, 2013).

It is possible that ectopic fat may be present even before higher values of BMI are reached. Visceral adiposity is robustly associated with risk of cardiometabolic diseases. Some studies have shown a possible relationship between visceral adiposity and bone fragility. In the study of Zhang, Peterson, Su et al. (2015), it was found out that visceral adiposity is strong and inversely associated with trabecular and cortical BMD of the vertebra.

Another find related to obesity is that the adipose infiltration into muscles, support skeletal muscle fragility or sarcopenia, which is important for the BMD because its mechanical effect of the skeletal muscle in bone (ZHANG, PETERSON, SU et al., 2015). Few studies have examined longitudinal increases in BMI and body fat in men was associated with declines in muscle mass and bone mass (PASCO, GOULD, BRENNAN et al., 2014).

The diversity of the results in several studies could be related to various factors such as bone site, age, gender and ethnicity (there are many studies with eastern populations).

The main objective this study was to examine if lean mass and the adiposity are related with BMD in a eutrophic population of Brazilian adults, in different sites and gender.

\section{Methods}

One hundred Brazilian adults, aged 20-40 years were evaluated $(n=50$ women $26.4 \pm 5.1$ years old. and $n=50$ men $28 \pm 6.1$ years old). All the participants gave their written informed consent to participate in this study. Which was approved by the University of São Paulo Medical School (\# 1256/06).

The inclusion criteria were: (1) not engaged in regular physical activity over the previous six months as defined by the International Physical Activity Questionnaire (IPAQ); (2) and BMI between 18.5 a $29.5\left(\mathrm{~kg} / \mathrm{m}^{2}\right)$.

The characteristics of the individuals who participated in the study are described in Table 1.

\subsection{Procedures}

The anthropometric measurements were performed in accordance with the International Society for the Advancement of Kinanthropometry (ISAK) standard.

Body composition was assessed using bone densitometry with a dual energy X-ray absorptiometry (DXA) on a LUNAR-DPX apparatus (Madison Corporation. USA).

\subsection{Statistical analysis}

The data were analyzed in the SPSS 20.0 software. The Kolmogorov-Smirnov test was used to ascertain whether the continuous variables presented normal distribution. Spearman's correlation coefficient was used to correlate the dependent variable (BMD) with the independent variables (anthropometric characteristics and body composition). Multiple regression was used to evaluate the association between adiposity and bone density, adjusting for age, sex, and BMI. An alpha of 5\% was used for all statistical tests.

\section{Results}

After adjusting for age, sex, and BMI, total fat mass was inversely associated with total BMD $\left(\beta=-4.52 \mathrm{~g} / \mathrm{cm}^{2}, \mathrm{p}<0.01\right)$.

The Table 2 shows a positive correlation between BMD and heights; body mass; BMI and waist-hip ratio in the female group (except for height).

Lean mass and fat mass was positively correlated with BMD in the female groups in different sites (Table 3 ).

\section{Discussion}

The present study shows that BMI has a positive correlation with $\mathrm{BMD}$, which is supportive of previous research (3-5).

Table 1. Characteristics of the study population (anthropometric and age).

\begin{tabular}{|c|c|c|c|}
\hline Variables & $\begin{array}{c}\text { Whole group } \\
\text { Mean (SD) } \\
N=100\end{array}$ & $\begin{array}{c}\text { Female group } \\
\text { Mean (SD) } \\
N=50\end{array}$ & $\begin{array}{c}\text { Male group } \\
\text { Mean (SD) } \\
N=50\end{array}$ \\
\hline \multicolumn{4}{|l|}{ Anthropometrics } \\
\hline Height (cm) & $168.8(9.5)$ & $161.8(6.8)$ & $175.8(6.2)$ \\
\hline Body mass (kg) & $69.9(14.3)$ & $61.2(10.9)$ & $78.6(11.8)$ \\
\hline $\mathrm{BMI}\left(\mathrm{kg} / \mathrm{m}^{2}\right)$ & $24.3(3.6)$ & $23.2(3.7)$ & $25.3(3.3)$ \\
\hline Waist-hip ratio $(\mathrm{cm})$ & $81.7(7.6)$ & $77.9(7.6)$ & $86(0.5)$ \\
\hline
\end{tabular}

Legend: SD: Standard deviation; BMI: body mass index. 
Table 2. Correlation between Body Mineral Density (BMD) and anthropometrics.

\begin{tabular}{|c|c|c|c|}
\hline \multirow{2}{*}{ Variables } & $\begin{array}{c}\text { Whole group } \\
N=100\end{array}$ & $\begin{array}{c}\text { Female group } \\
N=50\end{array}$ & $\begin{array}{c}\text { Male group } \\
N=50\end{array}$ \\
\hline & $\begin{array}{c}\mathrm{BMD}\left(\mathrm{g} / \mathrm{cm}^{2}\right) \\
\mathrm{r}(\mathrm{p})\end{array}$ & $\begin{array}{c}\mathrm{BMD}\left(\mathrm{g} / \mathrm{cm}^{2}\right) \\
\mathrm{r}(\mathrm{p})\end{array}$ & $\begin{array}{c}\mathrm{BMD}\left(\mathrm{g} / \mathrm{cm}^{2}\right) \\
\mathrm{r}(\mathrm{p})\end{array}$ \\
\hline \multicolumn{4}{|l|}{ Anthropometrics } \\
\hline Height $(\mathrm{cm})$ & $.415(\mathrm{p} \leq 0.001)^{*}$ & $.160(.282)$ & $-.003(.987)$ \\
\hline Body mass (kg) & $.550(\mathrm{p} \leq 0.001)^{*}$ & $.435(.002)^{*}$ & $.107(.479)$ \\
\hline $\operatorname{BMI}\left(\mathrm{kg} / \mathrm{m}^{2}\right)$ & $.450(\mathrm{p} \leq 0.001)^{*}$ & $.372(.010)^{*}$ & $-.189(.207)$ \\
\hline Waist-hip ratio $(\mathrm{cm})$ & $.528(\mathrm{p} \leq 0.001)^{*}$ & $.383(.008)^{*}$ & $-.028(.855)$ \\
\hline
\end{tabular}

Legend: BMD: Body Mineral Density; BMI: body mass index; r: Spearman's correlation coefficient; * $\mathrm{P}<0.05$.

Table 3. Correlation between Body Mineral Density (BMD) and corporal composition.

\begin{tabular}{|c|c|c|c|c|}
\hline & & $\begin{array}{c}\text { Whole group } \\
N=100\end{array}$ & $\begin{array}{c}\text { Female group } \\
N=50\end{array}$ & $\begin{array}{c}\text { Male group } \\
N=50\end{array}$ \\
\hline & & $\mathrm{BMD}\left(\mathrm{g} / \mathrm{cm}^{2}\right)$ & $\mathrm{BMD}\left(\mathrm{g} / \mathrm{cm}^{2}\right)$ & $\operatorname{BMD}\left(\mathrm{g} / \mathrm{cm}^{2}\right)$ \\
\hline & & $\mathbf{r}(\mathrm{p})$ & $\mathbf{r}(\mathrm{p})$ & $\mathbf{r}(\mathrm{p})$ \\
\hline \multicolumn{5}{|l|}{ Arm } \\
\hline & Fat mass (\%) & $-.512(\mathrm{P} \leq 0.001)^{*}$ & $.020(.89)$ & $-.084(.58)$ \\
\hline & Soft Tissue (g) & $.460(\mathrm{P} \leq 0.001)^{*}$ & $.332(.02)^{*}$ & $.050(.73)$ \\
\hline & Fat mass (g) & $-.234(.02)^{*}$ & $.200(17)$ & $-.066(.66)$ \\
\hline & Lean mass (g) & $.618(\mathrm{P} \leq 0.001)^{*}$ & $.350(.01)^{*}$ & $.138(.36)$ \\
\hline \multicolumn{5}{|l|}{ Leg } \\
\hline & Fat mass (\%) & $-.527(\mathrm{P} \leq 0.001)^{*}$ & $.142(.34)$ & $-.177(.24)$ \\
\hline & Soft Tissue (g) & $.407(.001)^{*}$ & $.242(.10)$ & $-.087(.56)$ \\
\hline & Fat mass (g) & $-.293(.004)^{*}$ & $.176(.23)$ & $-.194(.19)$ \\
\hline & Lean mass (g) & $.520(\mathrm{P} \leq 0.001)^{*}$ & $.165(.26)$ & $-.020(.89)$ \\
\hline \multicolumn{5}{|l|}{ Trunk } \\
\hline & Fat mass (\%) & $-.330(.001)^{*}$ & $.288(.05)^{*}$ & $-.110(.46)$ \\
\hline & Soft Tissue (g) & $.530(\mathrm{P} \leq 0.001)^{*}$ & $.450(.00)^{*}$ & $-.005(.97)$ \\
\hline & Fat mass(g) & $.064(.54)$ & $.386(.00)^{*}$ & $-.057(.70)$ \\
\hline & Lean mass (g) & $.608(\mathrm{P} \leq 0.001)^{*}$ & $.391(.00)^{*}$ & $0.51(.73)$ \\
\hline \multirow[t]{4}{*}{ Body total } & Fat mass (\%) & $-.467(\mathrm{P} \leq 0.001)^{*}$ & $.231(.11)$ & $-.125(.40)$ \\
\hline & Soft Tissue (g) & $.554(\mathrm{P} \leq 0.001)^{*}$ & $.449(.00)^{*}$ & $-.015(.92)$ \\
\hline & Fat mass (g) & $-.108(.30)$ & $.332(.02)^{*}$ & $-.085(.57)$ \\
\hline & Lean mass $(\mathrm{g})$ & $565(\mathrm{P} \leq 0.001)^{*}$ & $.227(.12)$ & $.077(.61)$ \\
\hline
\end{tabular}

Legend: BMD: Body Mineral Density; r: Spearman's correlation coefficient; ${ }^{*} \mathrm{P}<0.05$.

However, after adjusting for age, sex and BMI, we found a negative association between fat mass and BMD. Accordingly, to the lean mass the association was positive in all the three group. These findings are the same as in the literature (VAN LANGENDONCK, CLAESSENS, LEFEVRE et al., 2002; PARK, SONG, SUNG et al., 2012; SHAO, LI, LIU et al., 2015; ZHU, HUNTER, JAMES et al., 2015).

We can explain the positive correlation between lean mass and BMD through the effects of the muscle in the bone. The muscle contraction promotes micro stretches in the bone, stimulating osteocytes and promoting the activation of the osteoblasts, leading to a bone remodeling. This leads to a mechanical overload to the bone and the piezoelectric effect also stimulates the osteoblasts (WONG, BEATTIE, MIN et al., 2014).

A study in postmenopausal women demonstrated that for every $5 \mathrm{~kg}$ increase in lean mass represented an increase in the BMD; however, this finding was not the same with the increase of $5 \mathrm{~kg}$ in fat mass (SHAO, LI, LIU et al., 2015).

A study in Chinese adults over 50 years showed that the lean mass was an independent factor for BMD of the lumbar spine, in femoral diaphysis and in hip. It was observed that the lean mass peak in this population was found between 50 and 59 years. From this age on, there is an inevitable fall of the lean mass associated with aging, favoring the development of osteopenia, osteoporosis and increasing the fracture risk. In this study they also found that there is an increased of fat mass with aging, mainly after 80 years, maintaining the BMI at the same, but with the fat mass occupying the lean mass place (JIANG, ZHANG, JIN et al., 2015).

With regards to adiposity, the link with BMD is not well known. Some previous studies have found no association between adipose tissue and bone mineralization and others that found negative relation (PARK, SONG, SUNG et al., 2012; ZHANG, PETERSON, SU et al., 2015; WONG, BEATTIE, 
MIN et al., 2014). In our study we found that fat mass has a negatively association with BMD in men, but not in women. This could be because more fat mass percentage in males are associated with increased visceral adiposity and bone and muscle fat infiltration (PARK, SONG, SUNG et al., 2012; HO-PHAM, NGUYEN, LAI et al., 2010; ZHANG, PETERSON, SU et al., 2015; WONG, BEATTIE, MIN et al., 2014).

The Chinese study revealed that fat mass had a positive relation with $\mathrm{BMD}$ in lumbar spine and no significant in other sites (JIANG, ZHANG, JIN et al., 2015). The post menopause women study also cited previously identified that the relation was positive between fat mass and DMO in lumbar spine, femoral diaphysis and whole body, but less important than the relation associated with lean mass. The explanation for this was that any gain of weight may promote an increase of mechanic overload, being fat mass or lean mass, and stimulates the osteoblasts, mainly in axial skeleton (SHAO, LI, LIU et al., 2015).

However, the accumulation of visceral fat is an independent factor for lower quality in bone tissue and for an increase in fracture risk. The bone and muscle fat infiltration would explain this association (ZHANG, PETERSON, SU et al., 2015; WONG, BEATTIE, MIN et al., 2014).

Wong, Beattie, Min et al. (2014) investigated the muscle density through computed tomography (CT) and demonstrated that this could be an indirect measure of adiposity. Small values of muscle density would be associated with a larger fat infiltration in muscles, decreasing the positive effects of this contraction in bone. This would lead to an increased fracture risk. Schafer, Vittinghoff, Lang et al. (2010) corroborates with this hypothesis showing that in 2672 men and women a small muscle density had a bigger relation with fracture risk.

In our study we found a negative association between fat mass and BMD in the whole group. However, when we stratified the group by sex, we observed a tendency of negative correlation but only in men. In the Wong, Beattie, Min et al. (2014) study, they identified that men have a larger visceral fat accumulation than women that lead to an increase of a fat infiltration in muscle and bone. This would make the bone become more fragile and would increase the fracture risk. This could be why we found these results.

Physical activity and a better nutrition are the two mainly factors that would make the lean mass predominated over fat mass in the BMI determination. They should be motivated for all and with our findings we can say that they are important elements in the prevention and in the osteopenia and osteoporosis control, leading consequently in the decreased of fracture risk (BOGL, LATVALA, KAPRIO et al., 2011; JIANG, ZHANG, JIN et al., 2015).

Study limitation: We believe that if we had a bigger number of men, the results would be more statistically significant. In women, the fat mass has a positive relation with DMO.

We consider that more studies should be made to establish the real association between fat mass and DMO, because the literature still shows conflicted data about it. Factors related to the metabolic and endocrine system and this repercussion in the bone tissue should be better known so we can understand better the relation between obesity and osteoporosis.

In our study the lean mass has a positive effect in BMD for eutrophic Brazilian adults, opposite of adiposity. Although when stratified by gender, in adult's women lean mass and adiposity have positive effects on BMD, which did not happen with men.

\section{References}

BIAN, P., LI, X., YING, Q., CHEN, J., JIN, X., YAO, J. and SHOU, Z. Factors associated with low femoral neck bone mineral density in very elderly Chinese males. Archives of Gerontology and Geriatrics, 2015, vol. 61, n. 3, p. 484-488. PMid:26279395. http://dx.doi. org/10.1016/j.archger.2015.08.010.

BOGL, LH., LATVALA, A., KAPRIO, J., SOVIJÄRVI, O., RISSANEN, A. and PIETILÄINEN, KH. An investigation into the relationship between soft tissue body composition and bone mineral density in a young adult twin sample. Journal of Bone and Mineral Research, 2011, vol. 26, n. 1, p. 79-87. PMid:20658559. http://dx.doi. org/10.1002/jbmr.192.

BREDELLA, MA., GILL, CM., GERWECK, AV., LANDA, MG., KUMAR, V., DALEY, SM., TORRIANI, M. and MILLER, KK. Ectopic and serum lipid levels are positively associated with bone marrow fat in obesity. Radiology, 2013, vol. 269, n. 2, p. 534-541. PMid:23861502. http://dx.doi.org/10.1148/radiol.13130375.

GOODPASTER, BH., KELLEY, DE., THAETE, FL., HE, J. and ROSS, R. Skeletal muscle attenuation determined by computed tomography is associated with skeletal muscle lipid content. Journal of Applied Physiology, 2000, vol. 89, p. 104-110.

GOWER, BA. and CASAZZA, K. Divergent effects of obesity on bone health. Journal of Clinical Densitometry, 2013, vol. 16, n. 4, p. 450-454. PMid:24063845. http://dx.doi.org/10.1016/j. jocd.2013.08.010.

HO-PHAM, LT., NGUYEN, ND., LAI, TQ. and NGUYEN, TV. Contributions of lean mass and fat mass to bone mineral density: a study in postmenopausal women. BMC Musculoskeletal Disorders, 2010, vol. 26, n. 11, p. 59.

HSU, YH., VENNERS, SA., TERWEDOW, HA., FENG, Y., NIU, T., LI, Z., LAIRD, N., BRAIN, JD., CUMMINGS, SR., BOUXSEIN, ML., ROSEN, CJ. and XU, X. Relation of body composition, fat mass, and serum lipids to osteoporotic fractures and bone mineral density in Chinese men and women. The American Journal of Clinical Nutrition, 2006, vol. 83, n. 1, p. 146-154. PMid:16400063.

JIANG, Y., ZHANG, Y., JIN, M., GU, Z., PEI, Y. and MENG, P. Aged related changes in body composition and association between body composition with bone mass density by body mass index in chinese han men over 50-year-old. PLoS One, 2015, vol. 10, n. 6, p. e0130400.

JOHNELL, O. and KANIS, JA. An estimate of the worldwide prevalence and disability associated with osteoporotic fractures. Osteoporosis International, 2006, vol. 17, n. 12, p. 1726-1733. PMid:16983459. http://dx.doi.org/10.1007/s00198-006-0172-4.

KIN, K., KUSHIDA, K., YAMAZAKI, K., OKAMOTO, S. and INOUE, T. Bone mineral density of the spine in normal Japanese subjects using dual-energy X-ray absorptiometry: effect of obesity and menopausal status. Calcified Tissue International, 1991, vol. 49, n. 2, p. 101-106. PMid:1913287. http://dx.doi.org/10.1007/ BF02565129.

PARK, JH., SONG, YM., SUNG, J., LEE, K., KIM, YS., KIM, T. and $\mathrm{CHO}, \mathrm{SI}$. The association between fat and lean mass and bone mineral density: the Healthy Twin Study. Bone, 2012, vol. 50, n. 4, p. 1006-1011. PMid:22306928. http://dx.doi.org/10.1016/j. bone.2012.01.015.

PASCO, JA., GOULD, H., BRENNAN, SL., NICHOLSON, GC. and KOTOWICZ, MA. Musculoskeletal deterioration in men accompanies increases in body fat. Obesity, 2014, vol. 22, n. 3, p. 863-867. PMid:23625641. http://dx.doi.org/10.1002/oby.20496. 
PLUIJM, SM., VISSER, M., SMIT, JH., POPP-SNIJDERS, C., ROOS, JC. and LIPS, P. Determinants of bone mineral density in older men and women: body composition as mediator. Journal of Bone and Mineral Research, 2001, vol. 16, n. 11, p. 2142-2151. PMid:11697812. http://dx.doi.org/10.1359/jbmr.2001.16.11.2142.

REID, IR. Relationships between fat and bone. Osteoporosis International, 2008, vol. 19, n. 5, p. 595-606. PMid:17965817. http://dx.doi. org/10.1007/s00198-007-0492-z.

SCHAFER, AL., VITTINGHOFF, E., LANG, TF., SELLMEYER, DE., HARRIS, TB., KANAYA, AM., STROTMEYER, ES., CAWTHON, PM., CUMMINGS, SR., TYLAVSKY, FA., SCHERZINGER, AL. and SCHWARTZ, AV. Body Composition S. Fat infiltration of muscle, diabetes, and clinical fracture risk in older adults. The Journal of Clinical Endocrinology and Metabolism, 2010, vol. 95, n. 11, p. E368-E372. PMid:20668037. http://dx.doi.org/10.1210/jc.2010-0780.

SHAO, HD., LI, GW., LIU, Y., QIU, YY., YAO, JH. and TANG, GY. Contributions of fat mass and fat distribution to hip bone strength in healthy postmenopausal Chinese women. Journal of Bone and Mineral Metabolism, 2015, vol. 33, n. 5, p. 507-515. PMid:25269857. http:// dx.doi.org/10.1007/s00774-014-0613-7.

SILVA, HG., MENDONÇA, LM., CONCEIÇÃO, FL., ZAHAR, SE. and FARIAS, ML. Influence of obesity on bone density in postmenopausal women. Arquivos Brasileiros de Endocrinologia e Metabologia, 2007, vol. 51, n. 6, p. 943-949. PMid:17934661. http:// dx.doi.org/10.1590/S0004-27302007000600008.

VAN LANGENDONCK, L., CLAESSENS, AL., LEFEVRE, J., THOMIS, M., PHILIPPAERTS, R., DELVAUX, K., LYSENS, R., VANDEN EYNDE, B. and BEUNEN, G. Association between bone mineral density (DXA), body structure and body composition in middle aged men. American Journal of Human Biology, 2002, vol. 14, n. 6, p. 735-742. PMid:12400034. http://dx.doi.org/10.1002/ajhb.10090.

VETTOR, R., MILAN, G., FRANZIN, C., SANNA, M., DE COPPI, P., RIZZUTO, R. and FEDERSPIL, G. The origin of intermuscular adipose tissue and its pathophysiological implications. American Journal of Physiology. Endocrinology and Metabolism, 2009, vol. 297, n. 5, p. E987-E998. PMid:19738037. http://dx.doi.org/10.1152/ ajpendo.00229.2009.

WONG, AK., BEATTIE, KA., MIN, KK., GORDON, C., PICKARD, L., PAPAIOANNOU, A. and ADACHI, JD. Peripheral quantitative computed tomography-derived muscle density and peripheral magnetic ressonance imaging-derived muscle adiposity: precision and associations with fragility fractures in women. Journal of Musculoskeletal o Neuronal Interactions, 2014, vol. 14, n. 4, p. 401-410. PMid:25524965.

ZHANG, P., PETERSON, M., SU, GL. and WANG, SC. Visceral adiposity is negatively associated with bone density and muscle attenuation. The American Journal of Clinical Nutrition, 2015, vol. 101, n. 2, p. 337-343. PMid:25646331. http://dx.doi.org/10.3945/ ajen.113.081778

ZHU, K., HUNTER, M., JAMES, A., LIM, EM. and WALSH, JP. Associations between body mass index, lean and fat body mass and bone mineral density in middle-aged Australians: The Busselton Healthy Ageing Study. Bone, 2015, vol. 74, p. 146-152. PMid:25652209. http://dx.doi.org/10.1016/j.bone.2015.01.015.
Received September 2, 2017 Accepted October 28, 2017 